\title{
音韻特徵を捉えた音声伸長・短縮の了解度への影響と適応話 速変換方法の提案
}

\author{
Difference in the Effect of Time-Expanded and Time-Contracted Speech on \\ Intelligibility by Phonetic Feature and Adaptive Rate Control Strategy
}

学生会員渋谷徹 ${ }^{\dagger \dagger}$, 渡辺瞳 ${ }^{*}$, 小林洋 介 $^{\dagger}$, 近藤和 弘 $^{\dagger}$

Toru Shibuya ${ }^{\dagger, \dagger \dagger}$, Hitomi Watanabe ${ }^{\dagger *}$, Yosuke Kobayashi $^{\dagger}$ and Kazuhiro Kondo ${ }^{\dagger}$

\begin{abstract}
We have been investigating the effect of speech rate alteration on Japanese speech intelligibility, especially the differences caused by phonetic feature. We evaluated this difference in intelligibility using the Japanese Diagnostic Rhyme Test (DRT) on artificially speed-altered speech, such as time-expanded speech (1.6 times the original length, or $60 \%$ time expansion) and time-contracted speech (0.6 times the original length). Artificial speaking rate alteration was shown to have some effect or degradation on the Japanese speech intelligibility depending on the phonetic feature, initial consonant feature, and succeeding vowel context. Nasal and voiced affricates were relatively unaffected by speed alteration. Syllables with vowel context /i/ showed $10 \%$ higher intelligibility when time-expanded. Furthermore, we showed that the intelligibility was affected by only the time length of the initial consonant by comparing the evaluation results of simple expansion/contraction and phonetic expansion/contraction. These results suggest guidelines for feature-dependent intelligible speed alteration methods.
\end{abstract}

キーワード : 話速変換, 日本語了解度, DRT(Diagnostic Rhyme Test), 音韻特徴, 映像音声同期

\section{1. ま え がき}

放送番組などの視聴において，話す速度が速いと音声が 聞きとりにくいと感じることがあるが，その解決手段のひ とつに話す速度を変える話速変換がある. 話速変換の研究 および実用化に関しては,「ゆっくり話すとわかりやすい」 等の先行研究 ${ }^{1)}$ でもその効果が報告されている. リアルタ イム処理においては，話速伸張を行ったことにより絶対時 間に対する遅れが生じてしまうという問題があるので，無 音区間を短縮して音声伸長の時間に割り当てる手法を取り 入れて時間遅れの吸収を行っている.さらに，言語間のポー ズ（“間”）の時間長制御と有声区間の伸長倍率の制御方法 に関する検討 ${ }^{2)}$ や無声区間の伸長方式の検討 ${ }^{3)}$, 言語発声 時の特徵を捕らえた“はじめゆっくり徐々に早く”の制御手

2012 年 4 月 8 日受付, 2012 年 7 月 8 日再受付, 2012 年 8 月 3 日採録 †山形大学 大学院理工学研究科

（干 992-8510 米沢市城南 4-3-16, TEL 0238-26-3319)

††日本電気通信システム（株）

（率 980-0021 仙台市青葉区中央 3-4-7，TEL 022-212-5917）

*仙台高等専門学校

† Graduate School of Science and Engineering, Yamagata University (3-16 Jonan-4chome, Yonezawa-city, Yamagata, 992-8510 Japan) †† NEC Communication Systems, LTD.

(4-7, Chuo-3chome, Aoba-ku, Sendai-city, Miyagi 980-0021 Japanx)

* Sendai National College of Technology
法の検討 ${ }^{4)}$ など，話速変換と時間制御に関する研究が進め られてきた。いずれも話速変換を行う区間を定めてその区 間内を一律に伸長する方法であり，音韻種別での影響を調 査したものはなかった。また，これらの先行研究での評価指 標は，主に高齢者を対象にした “ゆっくり感”や“聞きやす さ”を尺度としており，文献 3) では，高齢者の場合に原音 で $42.9 \%$ だった聞き取りやすさが伸長率 1.4 倍で $85.7 \%$ に 向上したことが報告されている.

禰寝らは難聴者向けにピッチを変えずに速度を遅くする リアルタイム小型端末を開発し5)，これらの装置が実用に 供されている。この装置の話速変換手法は，パワーが大き い区間だけを閾值判定して，1.25 倍や 1.5 倍で話速変換を 行っている方式であり，音韻種別での影響を調査したもの ではない。この装置を用いて，種々の時間分解能をもつ難 聴者に対して評価を行った結果，話速変換した音声の単語 明瞭度の向上が得られなかったことと，聞き取りやすさが 被験者の時間分解能に依存していることを明らかにした上 で，時間分解能が悪い難聴者に対しての補聴効果が期待で きると結論付けしている ${ }^{6)}$. 他の音声伸張に関する研究で は，単音節の子音部のみを 2 倍に伸長した条件で中等度感 音性難聴者を対象に行った評価の結果，鼻音や半母音で明 瞭度の向上が見られたとの報告 ${ }^{7)}$ があり，難聴者向けにも 話速変換が有効であると考えられる，一方，音声短縮につ 
いては，視覚障がい者向けのテキスト音声読み上げ装置で の実用化がある．視覚障がい者においては，短い時間で効 率よく情報を得たいため，早い話速のときでも聞き取りや すい合成音声が求められており，テキスト合成エンジンの 高性能化が論じられている ${ }^{8)}$ 。これらの用途における話速 は 20 モーラ/秒といった超早口音声で, 例えば, ニュース 音声の通常の速さ 8.5 モーラ/秒 ${ }^{4)}$ に比べると 2.5 倍程度 の速度である.

このように話速変換に関する先行研究では, 螖牛の劣化 が主要因の老人性難聴に対する聞き取りやすさの評価が主 体であったこと, 話速短縮の場合は視覚障がい者向けの超 早口音声が対象であったことがあげられ，音韻種別に了解 度の影響を調査した研究はなされていなかった。

そこで，本研究では，伸長することで了解度が向上する 音韻や，短縮しても了解度が低下しない音韻といったよう な日本語音声の音韻の特徵に着目したときの話速と了解度 の関係を調査し，適応的に音声を伸長したり短縮したりす ることで，ゆっくりの速度でも大きな時間遅れがない音声 伸長方式や，早聞きでも了解度が低下しない音声短縮方式 といった適応話速変換方式による聞き取りやすい音声信号 の実現を目指している. なお，本研究は現段階では高齢者 や難聴者に特定せずに検討を進めている.

本論文では，はじめに話速変換した音声信号の了解度を 測定する方法として用いた二者択一型の了解度試験につい て述べる. 次いで, 話速と音韻の関係を調査するために行っ た，原信号の時間長の 1.6 倍の音声伸張と 0.6 倍の音声短縮 の了解度試験（単純伸長・短縮試験）について述べる. 次に, 語頭子音と後続母音の伸長や短縮の影響を調査するために 行った, 語頭子音のみを伸長した場合や後続母音以外を短 縮した場合といったような音韻のみの伸長や短縮パターン での了解度試験（CV 伸長・短縮試験）について述べる。こ れらの試験結果を元に, 音声伸長時に伸長する音韻と伸長 しない音韻, 音声短縮時に短縮してよい音韻, 短縮しない 音韻を整理し, 適応話速変換方法を提案する. また, 映像 音声の相対時間差の観点から適応話速変換の時間的な効果 を示し，最後にまとめと今後の課題を述べる.

\section{2. 了解度の試験方法}

\section{1 了解度試験（DRT）の方法}

本研究では，音声を時間伸長（あるいは短縮）すること により了解度が向上（あるいは劣化）する音韻や逆に変化 がない音韻を調査することで，了解度が向上する音韻だけ を伸長する, あるいは, 劣化する子音は短縮しない, といっ た適応話速変換方法を提案することにある.

話速と音韻の関係を調査するにあたっては，主観音質の 評価手法として, 受聴音のわかりやすさを評価する明瞭度・ 了解度試験である Diagnostic Rhyme Test (DRT) ${ }^{9)}$ を用 いた. DRT は語頭一音素の夕異なる単語対を用いた了解度 試験で，単語対のいずれか一方を試験者に聴取させる二者
択一型の評価試験である。本研究では言語的な文脈の影響 を排除し、音韻の識別に集中したい意図があり，DRT を使 用して単語了解度を計測することとした，また，DRT は明 確に実験方法が定義されており、PC を使った実験の実施 や結果の処理が簡単であることや，被験者に特段の訓練を 必要としない点なども DRT を選択した理由である.

本研究では, 文献 9) で報告されている日本語の 2 モーラ 単語対リストを用いた。この単語対は, 有声性（Voicing）, 鼻音性 (Nasality), 継続性 (Sustention), 不規則性 (Sibilation）, 拗音性（Graveness）および集中性（Compactness）の 6 種類の音韻特徵に分類されており，それぞれ 10 単語対（各 20 単語）から構成される. また, この 120 単 語の語頭子音（initial consonant）は, 鼻音（nasal: $/ \mathrm{m} /$, /n/ (22 単語)), 有声破擦音 (voiced affricate: /z/, /dz/ ( 7 単語) ), 有声破裂音（voiced plosives: /b/. / d /, /g/ (25 単語)), 半母音・流音 (semivowel and liquid: $/ \mathrm{y} /$, $/ \mathrm{w} /, / \mathrm{r} /$ (8 単語) ), 無声破擦音 (unvoiced affricate: /s/, $/ \mathrm{S} / \mathrm{h} / \mathrm{ts} /$ (17 単語)），無声破裂音（unvoiced plosives: $/ \mathrm{p} /, / \mathrm{t} /, / \mathrm{k} /$ (30 単語)), 渡り音 (glide: /h/ (11 単語)) の七つの子音特徵に分類することができる. なお, 子音に 後続する第一音節の母音（succeeding vowel）は日本語の 五つの母音/a/, /i/, / u/, /e/, /o/が各 24 単語ずつ均等 に配列されている.したがって, 本 DRT を適用すること で，話速と音韻の関係を比較的簡単に評価することが可能 である。

\section{2 話速変換方法}

話速変換の音声加工には，フリーソフトの Praat $^{10)}$ を用い た. Praatは Pitch Synchronous Overlap Add (PSOLA) 法を使用しており，ピッチを変えずに伸張短縮を行えるも のである．原信号に対して 1.6 倍の時間に伸長した “1.6xslow”と 0.6 倍の時間に短縮した “0.6x-quick”，原信号と 同じ速度の “1.0x-altered”を同ツールで加工して作成した (図 1).この 3 種類に原音 “original” を加えて試験を行った.

ここで, 伸長倍率については先行研究の文献 2)～6) で は 1.0 倍〜 1.5 倍を, 文献 7$)$ では 2.0 倍を用いていること, 短縮倍率については音声付映像速覧（いわゆる “早見早聞 き”）では $0.5 〜 0.8$ 倍が使用されていること，および，話 速を 0.4 倍〜 2.0 倍（0.2 倍刻み）で行った本研究の基礎実 験段階での聴取試験の結果から, 伸長と短縮の両端での効 果を測定することとし，“伸長倍率は 1.6 倍”，“短縮倍率は 0.6 倍”とした.

また, 話速変換時の分析合成に伴う信号処理歪みを全サ ンプルで共通に与え，極力話速変換の影響のみを評価する ために，敢えて話速不変のサンプルにも分析合成処理を適 用することとし，“1.0x-altered”も試験対象に加えた.

\subsection{DRT 条件と試験方法}

了解度試験の実施方法と条件について, 前述のコーパス や話速のほか, 重畳したノイズ, 提示方法と回答入力方法, 被験者，正答率について以下説明する。また，これらの試 
験条件を表 1 に示した。

・ノイズ : 周りが騒がしい環境下での利用を想定してい るため，外乱としてバブルノイズ（マルチトーカノイズ : 男 女複数人の混合音声雑音) ${ }^{11)}$ を使用した。試験に使用する 120 単語の時間総和の信号レベルと同一レベルになるノイズ レベルを $0 \mathrm{~dB}$ としてレベル統制を行った. 試験に使用する ノイズレベルは，原音に対して0（音声と同じレベル），4， 8，12，16 dB のバブルノイズを印加したものとした。また， 比較用にノイズを重畳しない“ノイズなし（no-noise）”を 加えて試験を行った.

- 提示方法 : 発話者は 60 代女性の 1 種類で, 2 モーラ単 語の平均速度は 6.1 モーラ/秒である. 被験者に提示する 音声信号は，開始点はノイズ音とし，開始点から $300 \mathrm{~ms}$ 後に音声信号が重畳されるように時閒統制を行った（図 1 参照）。試験に用いた単語数は，120 単語 $\times$ 音声速度 4 種 類 $\times 6$ 種類の計 2,880 単語である. この 2,880 単語の提示 順番は被験者ごとにランダムに再生し，ヘッドホンで提示 した.

・回答入力 : 実際の試験は, 例えば，“ダク”が提示され たときに，被験者は「どちらの単語を発話したように聞こ えたか?」を PC 上に表示される応答入力のダイアログボッ クス（図 2）で選択する（この図の場合は誤答である）と いう手順である。選択後はすぐに次の単語の聴取試験に移 行する. 1 単語あたりの所要時間は 3 秒程度であり, 試験 全体の所要時間は約 2.5 時間である.

・被験者 : 被験者は日本語を母国語とする健聴者の 20 代 男性 6 名*とした．なお，提示音圧はすべての音源がはっき り聞こえるように，予め調整したレベルを被験者全員が使 用した. DRT においては，学習の影響が極めて小さい9) ことを確認しているので試験回数は 1 回とし, 繰り返し試 験は行わない。また，試験に先立ち，試験の方法や機器操 作に慣れてもらうことと健聴者であることを確認するため, 24 単語を使った簡単なトレーニングを実施した。 その結果 に極端な異常が見られないことから健聴者であることを確 認した。

- 正答率 : この試験は二者択一型の試験であるため, まっ たくでたらめに回答しても正答率が $50 \%$ にることから， 評価值としては式 (1) により偶発性を排除した調整正答 率 $^{9)}$ : CACRR (chance-adjusted correct response rate) を使用した。

$$
\text { 調整正答率 }(C A C R R)=\frac{\text { 正答数 }- \text { 誤答数 }}{\text { 総単語数 }}
$$

\footnotetext{
* DRT 試験は通常 $5 \sim 10$ 人程度で実施している. 本研究の基礎実験段階 で実施した試験結果や筆者らの報告 ${ }^{13)}$ では，6 名の場合でも有意差検 定で話速の違いが検出できていることから, 被験者数は 6 名とした.
}

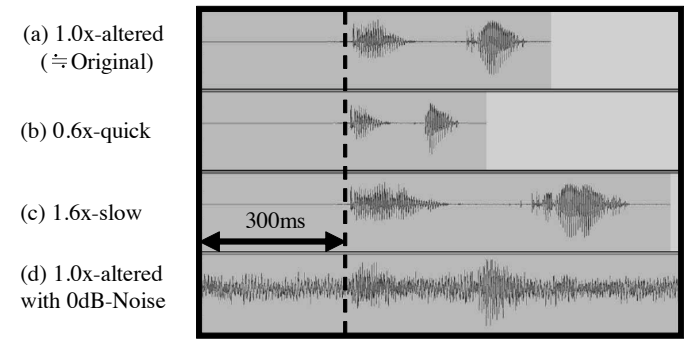

図 1 話速変換加工した音声信号の例 “ダク”

Waveform examples of artificially speed-altered speech ("daku").

表 1 単純伸長短縮試験の DRT 条件

DRT conditions for simple expansion and contraction.

\begin{tabular}{|c|c|c|}
\hline 項目 & 条件 & 種類 \\
\hline 単語リスト & 語頭子音の夕異なる2モーラ単語対 & $\begin{array}{l}60 \text { 単語対 } \\
\text { (120単語) }\end{array}$ \\
\hline 音声速度 & $\begin{array}{l}\text { 等速加工 } \quad(1.0 x \text {-altered }) \\
\text { ゆっくり (1.6x-slow) } \\
\text { 早く } \quad(0.6 x \text {-quick }) \\
\text { 原音 (original) }\end{array}$ & 4 種類 \\
\hline 話速変換 & Praat & - \\
\hline ノイズ種類 & バブルノイズ(マルチトーカノイズ) & 1 種類 \\
\hline ノイズレベル & $0,4,8,12,16 \mathrm{~dB}$, ノイズなし & 6種類 \\
\hline 被験者 & 20代男性（健聴者） & 6人 \\
\hline
\end{tabular}

\begin{tabular}{|c|c|c|c|}
\hline \multicolumn{3}{|c|}{ play controls } & 두용 \\
\hline - ta & $\mathrm{ru}$ (夕 & & r daku(タ゚ク) \\
\hline Replay & Next & 残り & \\
\hline
\end{tabular}

図 2 応答入力のダイアログ・ボックスの例 Example for selection input dialog box.

\section{3. 単純伸長・短縮試験の結果}

\section{1 音韻特徵別の了解度}

図 3 はノイズ量に対する全音韻特徵（120 単語）の正答 率を被験者別に算出した平均值を話速ごとに示したもので ある。この図から，“0.6x-quick”は “original”や“1.0xaltered”, “1.6x-slow”に比べて了解度が低下していること がわかる．話速 4 水準とノイズなしを含まないノイズレ心゙ ル 5 水準 $(0,4,8,12,16 \mathrm{~dB})$ の被験者内要因計画とした 二元配置分散分析の結果は, $[F(3,15)=38.78, p<0.001]$ で有意水準 $1 \%$ で有意であった．さらに有意水準 $5 \%$ で下位 検定を行ったところ, “original”と“1.0x-altered” 以外に 有意差がみられた。

図 3 から，"1.6x-slow" は "original”や や1.0x-altered” に比べて差がないことが観測できるが，ノイズレベル $12 \mathrm{~dB}$ および $16 \mathrm{~dB}$ では劣化している傾向が読み取れる.このこ とが上記分散分析では有意差がある結果になったと考えら れる。そこで，ノイズレベルを $0,4,8 \mathrm{~dB}$ の 3 種類に限定 して同様に分散分析を行ったところ, “original” との比較で は $p=0.062>5 \%$ ，"1.0x-altered"では $p=0.070>5 \%$ であり，共に差がないことがわかった。これらのことから， 


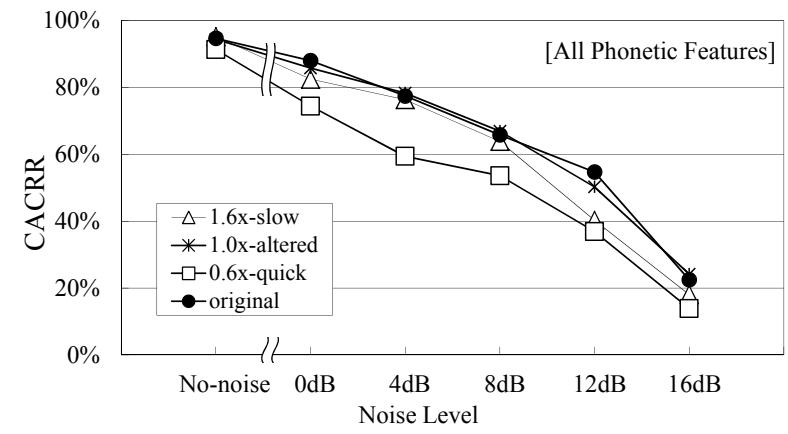

図 3 DRT 結果 (全音韻特徵)

DRT result of over all phonetic features.
ノイズを印加した状態においては, 単純伸長・短縮共に了 解度に影響していること, 音声伸長においてはノイズレべ ルが小さい範囲 $(0,4,8 \mathrm{~dB})$ では “1.0x-altered” との了 解度の差がないことがわかった。 なお，被験者ごとの個人 差は特に観測されなかった。

\section{2 先頭子音の特徵別の評価結果}

図 4 は話速と了解度の関係を調查するために, ノイズ条件 $(0,4,8,12,16 \mathrm{~dB})$ を集計したときの被験者別に算出した 正答率の平均值を, “1.0x-altered”に対する "1.6x-slow" の差分，および “1.0x-altered” に対する “0.6x-quick” の 差分として示した図で，先頭子音を七つの子音特徴別に分 類*したものである. 話速 4 水準とノイズレベル 5 水準の 被験者内要因計画とした二元配置分散分析の結果を求めた 後，有意水準 $1 \%$ で “1.0x-altered” と比較した下位検定を 行った結果で有意差があったものを図中の「**」あるいは 「*」に示した. また, レファレンス ("1.0x-altered") の平 均值に対する被験者の標準偏差を同図に示した.

これらの結果から，“1.6x-slow”においては無声破裂音 で了解度が向上する傾向がみられたが，他の子音特徴では 向上がみられなかった。 "0.6x-quick” では有声破裂音, 半 母音・流音，無声破擦音で劣化がみられた。一方では, 鼻 音，有声破裂音のように“1.0x-altered” と差がない音韻特 徵も見られた。このことから, 鼻音, 有声破裂音では両方 の速度で, 有声破擦音では伸長時に, 渡り音では短縮時に それぞれ了解度に影響を与えることなく話速変換できる可 能性があることがわかった。

\section{3 後続母音特徵別の評価結果}

図 5 は話速と了解度の関係を調査寸るために, ノイズ条件 $(0,4,8,12,16 \mathrm{~dB})$ を集計したときの被験者別に算出した 正答率の平均值を, “1.0x-altered” に対する "1.6x-slow", および “1.0x-altered” に対する “0.6x-quick” の差分とし て示した図で，五つの母音別に示している. 話速 4 水準と ノイズレベル 5 水準の被験者内要因計画とした二元配置分

*具体的には, 単語対である “ダク”と“タク”においては, “ダク (daku)” を提示したときの正答率は“有声破裂音/d/”に, “夕ク（taku）”を 提示したときの正答率は “無声破裂音 $/ \mathrm{t} /$ ” に分類した。 なお，これら の単語は，後続母音特徴では/a/に分類される。

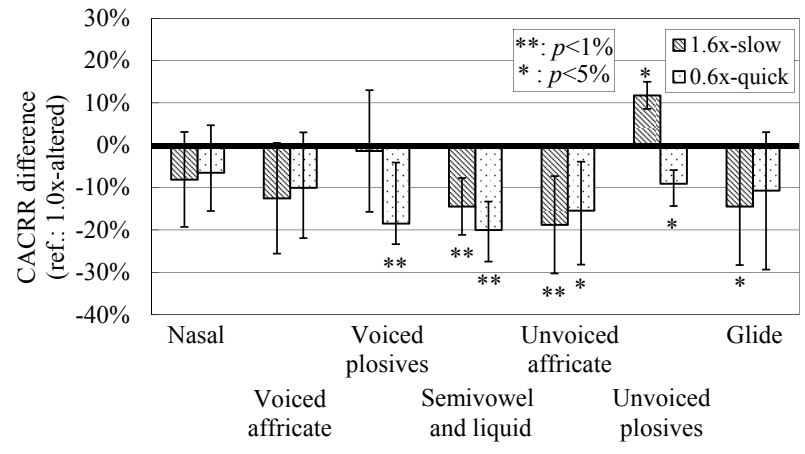

図 4 七つの子音特徴で分類した DRT 結果 Noise-averaged CACRR by seven consonant features.

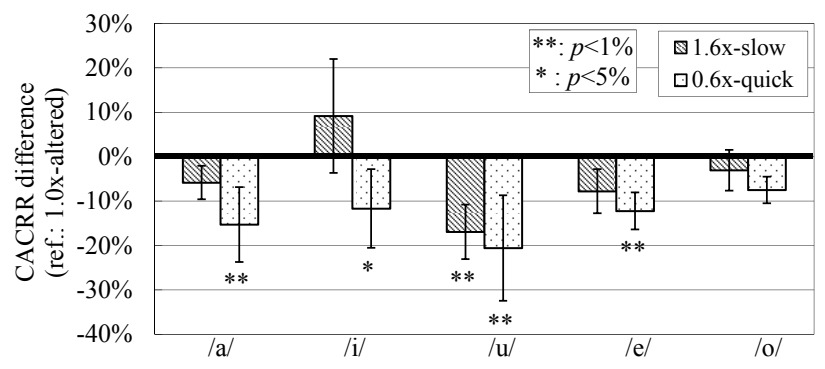

図 5 母音特徵で分類した DRT 結果 Noise-averaged CACRR by five vowel features.

散分析の結果を求めた後，有意水準 1\%で “1.0x-altered” と比較した下位検定を行った結果で有意差があったものを 図中の「**」あるいは「*」に示した。また，レファレンス (“1.0x-altered”) の平均値に対する被験者の標準偏差を同 図に示した.

これらの結果から，/u/は両方の速度で劣化がみられた。 “1.6x-slow”においては/i/で了解度が向上寸る傾向がみら れ，“0.6x-quick”では，/o/は大きく影響を受けないこと がわかる。このことから，/o/は両方の速度で，/a/と/e/ は伸長時にそれぞれ了解度に影響を与えることなく話速変 換できる可能性があることがわかった。

\section{4. 単純伸長・短縮試験の考察}

\section{1 先行論文との対比}

3.1 節で述べたように，ノイズレベル $0,4,8 \mathrm{~dB}$ におい ては, “1.6x-slow”は "1.0x-altered”や やoriginal” に対し て了解度の差がないことがわかった。この結果は, 難聴者 を対象としたノイズなしの環境で評価した結果, 音声伸張 で明瞭度の向上が得られなかった文献 6) の結果とも一致す る. しかし, 図 4 や図 5 からわかるように音韻特徵別に観 察すると, 無声破裂音や/i/のように了解度が向上寸る音韻 など, 音韻特徴によって話速と了解度の違いが出てくるこ とがわかった。

また，子音部伸張を行った文献 7) の結果によれば，鼻音 と半母音で明瞭度が向上したとの報告がある。この結果は, 単音節の $/ \mathrm{ma} /, / \mathrm{na} /, / \mathrm{ra} /$ の子音部のみ 2.0 倍に伸長した 


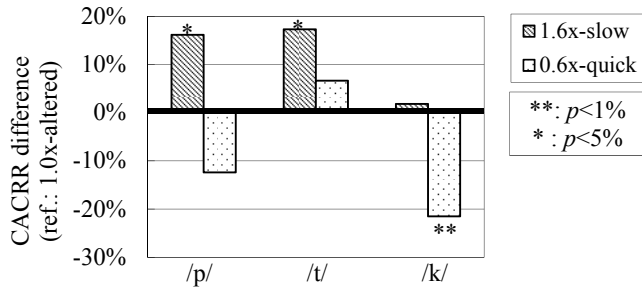

図 6 無声破裂音の DRT 結果

Noise-averaged CACRR for unvoiced plosives.

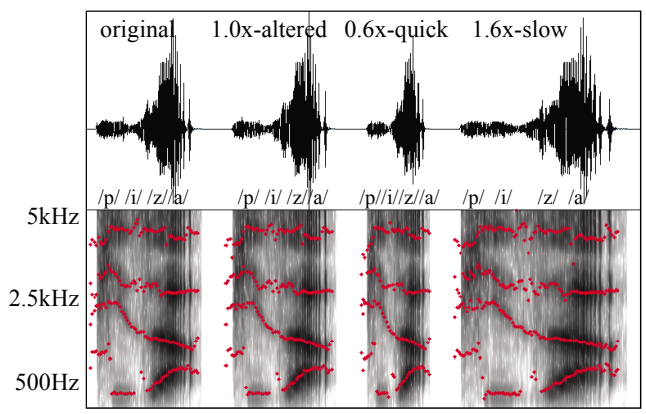

図 7 音声波形とフォルマント “piza” Waveform and formants of "piza" at various speed.

条件において明瞭度の改善に有効であったという報告であ る. 本研究の試験結果では鼻音では変化がなく半母音・流 音では劣化した一方，無声破裂音で向上がみられた。この 違いは，試験で使用したコーパスや伸長速度，試験条件な どの違いによるものと考えられ，一対一で比較することは 困難であるが，子音伸長による効果が期待できるという観 点では一致しており，今後さらに効果のある音韻について 研究を深める意義があると考える.

\section{2 無声破裂音の分析}

図 4 に示すように，音声伸張 “1.6x-slow” 時に無声破裂音 では “1.0x-altered”に比べて了解度の向上がみられた．図 6 は図 4 の無声破裂音の結果をさらに音素 $(/ \mathrm{p} /, / \mathrm{t} /, / \mathrm{k} /)$ ごとに示したものである. “1.6x-slow”においては, 音素/p/ と/t/が有意に向上していることがわかる.

DRT 単語に含まれる “piza” は，“1.6x-slow”で了解度 の向上がみられた音素/p/と/i/の組合せである. 図 7 に話 速ごとの音声波形およびフォルマント波形を示した。/p/ は低域の周波数が支配的な子音であること，および，/i/は 他の母音に対して，F1 が低く F2 が高いという特徵を持つ 口蓋音であることから，/p/から/i/へのフォルマント遷移 時間が音声伸張により安定化された効果によって, これら の音素では音声伸張により了解度が向上したと考えられる.

したがって，子音伸長処理においては子音区間とフォル マント遷移区閒をあわせて伸長する必要があると考えられ る. 適応話速変換においては，子音区閒や母音区間のみな らず，その間の遷移時閒の扱いについても検討する必要が あり今後の課題と考える.

\section{CV 伸長・短縮試験の方法}

\section{$5.1 \mathrm{CV}$ 伸長と CV 短縮の試験パターン}

第 3 章の単純伸長・短縮試験で了解度が向上する音韻や劣 化する音韻が明らかになったので，次に子音（consonant） ごとや母音（vowel）ごとの伸長および短縮，すなわち CV 伸長および CV 短縮での了解度の変化を測定することを目 的に, 以下の伸長・短縮パターンでの音声加工を実施した. なお，すべての条件での試験を実施すると試験単語数が膨 大になることから, 単純伸長・短縮試験の結果で特徴があつ た音韻の単語のみを抜き出して試験を実施することとした.

図 8 は 2 モーラの単語の “語頭子音十後続母音十第 2 子 音十第 2 母音 $(\mathrm{C} 1+\mathrm{V} 1+\mathrm{C} 2+\mathrm{V} 2)$ ）の場合の $\mathrm{CV}$ 伸長およ び CV 短縮の方法を説明するための図である. CV 伸長にお いては，了解度の向上があった無声破裂音 $(/ \mathrm{p} /, / \mathrm{t} /, / \mathrm{k} /)$ と後続母音/i/を含む単語と DRT の対となる単語の計 62 単語に対して，図 8(a) に示すような，語頭子音 $\mathrm{C} 1$ のみ伸 長する “1.6x-C”，語頭子音 $\mathrm{C} 1$ と後続母音 V1 を伸長する “1.6x-CV”，および，後続母音 V1 のみ伸長する “1.6x-V" の 3 パターンの音声伸長を行った。

$\mathrm{CV}$ 短縮においては，短縮して了解度の劣化があった有 声破裂音 $(/ \mathrm{b} /, / \mathrm{d} /, / \mathrm{g} /)$ ，半母音・流音 $(/ \mathrm{r} / \mathrm{w} / \mathrm{w} /$, $/ \mathrm{y} /)$ ，無声破擦音 $(/ \mathrm{s} /, / \mathrm{s} /, / \mathrm{ts} /)$ および母音 $(/ \mathrm{a} /$, $/ \mathrm{u} /, / \mathrm{e} /$ ) を含む単語と DRT の対となる単語の計 80 単語 に対して, 図 8(b) に示すような, 語頭子音 $\mathrm{C} 1$ 以外を短縮 する “0.6x-nC”, 語頭子音 $\mathrm{C} 1$ と後続母音 $\mathrm{V} 1$ 以外を短縮 する “0.6x-nCV”，および，後続母音 V1 以外を短縮する “0.6x-nV”の 3 種の音声伸長を行った.

子音区閒や母音区間のラベリングは，音声波形およびフォ ルマント, ピッチを観察しながら行った。 また, 子音から 母音への遷移区間（フォルマント遷移区間）は子音区間に 含めて加工した．なお，これらの試験パターンのうちの一 部では $\mathrm{C} 1$ と V1 で時間伸長（短縮）率が異なる事象，す なわちモーラの等時性に反する事象になるが，音源の聴取 実験では特に違和感を覚えることはなかった。

\section{2 その他の試験条件}

$\mathrm{CV}$ 伸長・短縮試験の話速の種類は上記 $\mathrm{CV}$ 伸長 3 パ ターンと $\mathrm{CV}$ 短縮 3 パターンに，比較基準としての単純伸 長 “1.6x-slow”，単純短縮 “0.6x-quick” および等速の加工 “1.0x-altered” の 3 パターンを加えて DRT により了解度 試験を実施した。なお，その他の DRT の条件は単純伸長・ 短縮の評価試験と同じ条件（表 1）に設定した.

この試験にあたっては，特に伸長と短縮は分けずに 9 パ ターンを同時に実施した。また，途中休息を可とした。な お，試験に用いた単語数は，伸長 62 単語 $\times$ 音声速度 5 種類 メノイズ 6 種類の 1,860 単語と短縮 80 単語 $\times$ 音声速度 5 種 類×ノイズ 6 種類の 2,400 単語から共通の “1.0x-altered" の 192 単語を引いた合計 4,548 単語でおおよその所要時間 は 3.5 時間である。 


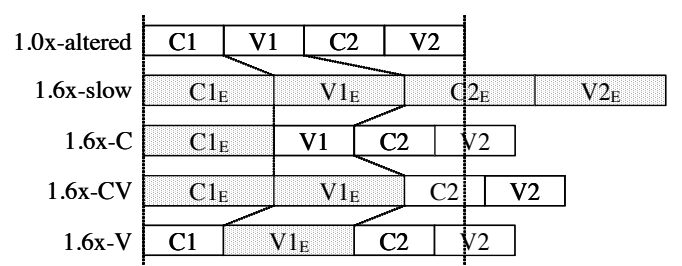

(a) CV 伸長 / CV Time-expand

\begin{tabular}{|c|c|c|c|c|c|}
\hline $1.0 \mathrm{x}$-altered & $\mathrm{C} 1$ & V1 & & 2 & $\mathrm{~V} 2$ \\
\hline $0.6 \mathrm{x}$-quick & $\mathrm{Cl}_{\mathrm{C}}$ & $\mathrm{C} 2 \mathrm{C}$ & $2 \mathrm{C}$ & & \\
\hline $0.6 \mathrm{x}-\mathrm{nC}$ & C1 & $1_{C}$ & & $2 \mathrm{C}$ & \\
\hline $0.6 \mathrm{x}-\mathrm{nCV}$ & $\mathrm{C} 1$ & V1 & $\mathrm{C} 2$ & $\mathrm{~V} 2$ & \\
\hline $0.6 x-n V$ & $\mathrm{C} 1_{C}$ & & & & \\
\hline
\end{tabular}

(b) CV短縮 / CV Time-contracted

\begin{tabular}{|c|c|}
\hline & :Original time length \\
\hline$* *_{E}$ & :Time-expand to $1.6 \mathrm{x}$ \\
\hline & Time-contracted to $0.6 \mathrm{x}$ \\
\hline
\end{tabular}

図 $8 \mathrm{CV}$ 伸長・短縮のパターン

Speed alteration examples of $\mathrm{CV}$ expansion and contraction.

\section{6. $\mathrm{CV}$ 伸長・短縮試験の結果}

\section{1 子音特徵別の評価結果}

図 9 は，ノイズ量に対する被験者別に算出した正答率の平 均值を, $\mathrm{CV}$ 伸長と $\mathrm{CV}$ 短縮の各パターンの "1.0x-altered" に対する差分を示した図である。図 9(a) は試験に用いた 62 単語のうち先頭子音が無声破裂音 30 単語*を, 図 9(b) は試験に用いた 80 単語のうちの有声破裂音 25 単語, 半母 音・流音 8 単語, 無声破擦音 17 単語の計 50 単語**を用い た. 音声伸長と音声短縮それぞれについて, 話速 5 水準と ノイズレベル 5 水準の被験者内要因計画とした二元配置分 散分析の結果を求めた後, 有意水準 $1 \%$ で “1.0x-altered” と比較した下位検定を行った結果で有意差があったものを 図中の「**」あるいは「*」に示した。また，レファレンス ("1.0x-altered") の平均值に対する被験者の標準偏差を同 図に示した.

CV 伸長においては，“1.6x-C”の了解度は，“1.6x-slow” と同程度であった. すなわち, 無声破裂音のみを伸長するこ とで，単純伸長と同程度に了解度が向上することがわかっ た. CV 短縮においては, “0.6x-nC”, “0.6x-nCV”のよう に一部を短縮しても“1.0x-altered”と同程度の了解度が得 られた。すなわち，有声破裂音，半母音・流音，無声破擦 音の子音のみを短縮しないことで, “0.6x-quick”に比べて 了解度が向上することがわかった。

\section{2 母音特徵別の評価結果}

図 10 は母音特徵別の評価結果で，ノイズ量に対する被 験者別に算出した正答率の平均值を, $\mathrm{CV}$ 伸長・短縮の各パ

*残りの 32 単語は先頭子音が無声破裂音ではない後続母音/i/の単語と無 声破裂音の単語対のもう一方の単語である.

**残りの 30 単語は先頭子音が有声破裂音, 半母音・流音, 無声破擦音で はない単語対の一方の単語である.
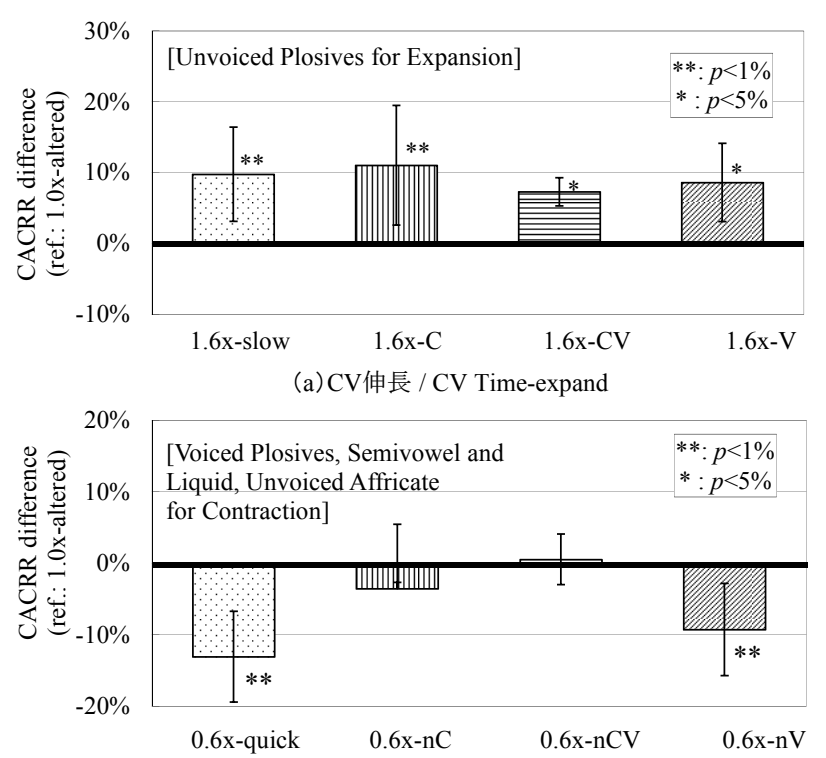

(b) CV短縮 / CV Time-contracted

図 $9 \mathrm{CV}$ 伸長・短縮における子音特徴での正答率の変化 Noise-averaged CACRR by $\mathrm{CV}$ expansion and contraction.

ターンの “1.0x-altered”に対する差分を示した図である. 図 10(a) は試験に用いた 62 単語を母音特徵別に分類した (/a/ : 10 単語, /i/ : 24 単語, /u/ : 10 単語, /e/ : 10 単 語, /o/ : 8 単語). 図 10(b) は試験に用いた 80 単語を母 音特徴別に分類した $(/ \mathrm{a} /: 16$ 単語, /i/ : 16 単語, / $\mathrm{u} /$ : 18 単語, $/ \mathrm{e} /: 14$ 単語, $/ \mathrm{o} /: 16$ 単語 $)$. 音声伸長と音声短 縮それぞれについて，話速 5 水準とノイズレベル 5 水準の 被験者内要因計画とした二元配置分散分析の結果を求めた 後，有意水準 $1 \%$ で “1.0x-altered”と比較した下位検定を 行った結果で有意差があったものを図中の「**」あるいは 「*」に示した。 また，レファレンス ("1.0x-altered”) の平 均值に対する被験者の標準偏差を同図に示した。 CV 伸長 において 4 種類のパターンで有意差があったのは $/ \mathrm{u} /$ であ る. 母音 $/ \mathrm{u} /$ を含む音節では，子音を伸張したことによる 了解度の劣化があることがわかった。 CV 短縮においては, 母音/i/では “0.6x-nCV” 以外は “1.0x-altered”に比べて 有意に劣化した．すなわち，母音/i/を含む音節では $\mathrm{C} 1$ と V1 両方を短縮しないほうが短縮時の了解度向上につながる ことが伺える。この特徽は母音/i/のみで観測されており， 4.2 節で述べた $/ \mathrm{i} /$ が口蓋化された母音であることとの関係 が示唆されたと考えられる。

\section{7. 適応話速変換の提案}

\section{1 応話速変換の方法}

3 章の単純伸長・短縮試験の結果および 6 章の $\mathrm{CV}$ 伸長・ 短縮試験の結果を元に，効果のある音韻だけを伸長する，あ るいは, 劣化する子音は短縮しない, といった音韻の特徵 を捉えた適応話速変換のひとつの例を表 $\mathbf{2}$ に示した．この 例を用いることで，単純伸長とは違って時間遅れをさほど 


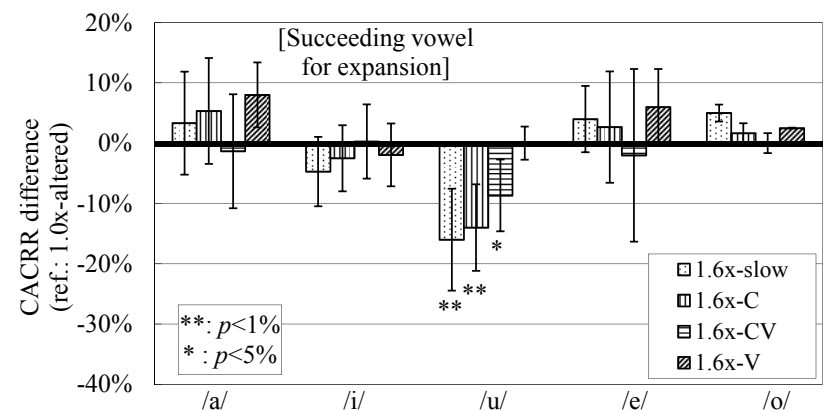

(a) CV伸長 / CV Time-expand

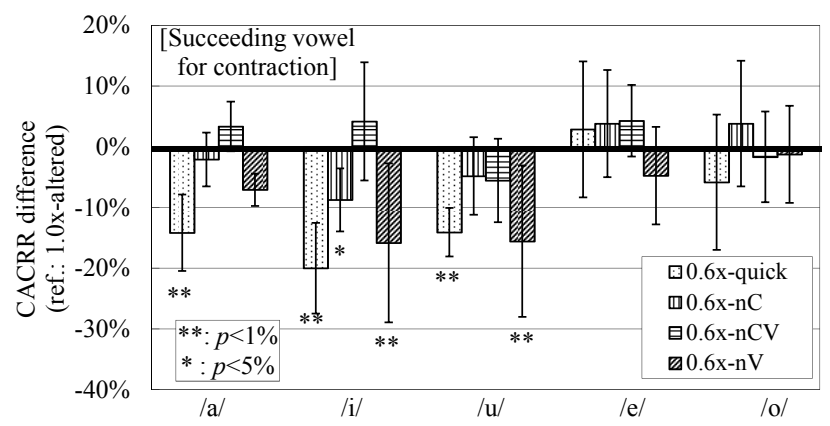

(b) CV短縮 / CV Time-contracted

図 $10 \mathrm{CV}$ 伸長・短縮による母音特徴の正答率の変化 Noise-averaged CACRR by CV expansion and contraction.

表 2 適応話速変換方法の例

Guidelines for adaptive speech rate control.

\begin{tabular}{|c|c|c|c|c|c|c|c|c|c|c|}
\hline \multirow[t]{3}{*}{ Initial Consonant } & \multicolumn{10}{|c|}{ Succeeding vowel } \\
\hline & \multicolumn{5}{|c|}{ Time expansion } & \multicolumn{5}{|c|}{ Time contraction } \\
\hline & $/ \mathrm{a} /$ & /i/ & $/ \mathrm{u} /$ & /e/ & /o/ & $/ \mathrm{a} /$ & /i/ & $/ \mathrm{u} /$ & e/ & $10 /$ \\
\hline Nasal: $/ \mathrm{m} /, / \mathrm{n} /$ & & & 0 & & & Cont & Cont & Cont & Cont & Cont \\
\hline $\begin{array}{l}\text { Voiced Affriate: } \\
|z|, / d z /\end{array}$ & & & 0 & & & Cont & Cont & Cont & Cont & Cont \\
\hline $\begin{array}{l}\text { Voiced Explosion: } \\
\text { /b/,/d/,/g/ }\end{array}$ & & & 0 & & & $\mathrm{nC}$ & $\mathrm{nCV}$ & $\mathrm{nC}$ & $\mathrm{nC}$ & Cont \\
\hline $\begin{array}{c}\text { Semivowel and } \\
\text { Liquid: } / \mathrm{y} /, / \mathrm{w} /, / \mathrm{r} /\end{array}$ & 0 & 0 & 0 & 0 & 0 & $\mathrm{nC}$ & $\mathrm{nCV}$ & $\mathrm{nC}$ & $\mathrm{nC}$ & Cont \\
\hline $\begin{array}{c}\text { Unvoiced Affriate: } \\
/ \mathrm{s} /, / \int /, / \mathrm{ts} /\end{array}$ & 0 & 0 & 0 & 0 & 0 & $\mathrm{nC}$ & $\mathrm{nCV}$ & $\mathrm{nC}$ & $\mathrm{nC}$ & Cont \\
\hline $\begin{array}{c}\text { Unvoiced Explosion: } \\
/ \mathrm{p} /, / \mathrm{t} /, / \mathrm{k} /\end{array}$ & Cexp & Cexp & Cexp & Cexp & Cexp & & & & & Cont \\
\hline Glide: /h/ & 0 & 0 & 0 & 0 & 0 & Cont & Cont & Cont & Cont & Cont \\
\hline
\end{tabular}

気にせずに音声伸張できることや，レコーダ再生時の“早 聞き”のさらなる時間短縮，あるいは，同一の再生速度で の了解度向上につながると考える.

\section{2 時間長に対する一考察}

適応話速変換方法の利点の一つに, 効果のある音韻だけを 伸長・短縮することで, 音声再生の時間短縮に寄与できるこ とがあげられる. 図 11 は, DRT で使用した 120 個の単語 の原音の速度 “1.0x-altered” の平均值（335 ms）を基準と して, "0.6x-quick", "0.6x-nC", "1.6x-C", "1.6x-slow" の時間長の計測結果を示したものである.

例えば，単純伸長 “1.6x-slow” の場合は，原音の速度 $1.0 \mathrm{x}$ に比べて平均で $201 \mathrm{~ms}$, 最大で $286 \mathrm{~ms}$ の時間遅れとなる

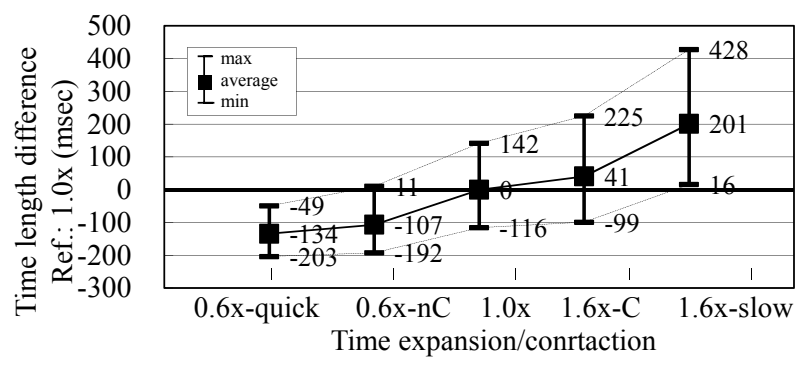

図 11 話速パターンによる時間長変化 Time length difference by speed alteration.

可能性があるが，“1.6x-C" では平均で $41 \mathrm{~ms}$ ，最大で 83 $\mathrm{ms}$ の時間遅れにとどめることができる効果がある.

次に映像と音声の時間ずれの観点で考察する. 音声の時 間遅れの解消を目的とした先行研究文献 4) によると文内休 止時間の平均が $400 \mathrm{~ms}$, 許容限が $200 \mathrm{~ms}$ であることや, テレビの映像と音声の相対時間差の調査報告 ${ }^{13)}$ によると 映像と音声遅れの場合の相対時間差の許容限が $182 \mathrm{~ms}$ で

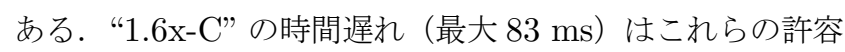
值に収まっていることから, 適応話速変換の手法を取り入 れることによって, 映像音声の同期についての問題も解決 でき，時間遅れを気にしない音声伸長システムに適用でき る可能性が示唆される. また, 音声の夕を単純伸長したと きの映像と音声の “ずれ” の検知限と許容限が，4 モーラ単 語では約 $230 \mathrm{~ms}$ と $333 \mathrm{~ms} ， 7,8$ モーラ単語においては 約 $407 \mathrm{~ms}$ と $574 \mathrm{~ms}$ との報告がある ${ }^{14)}$.このことから適 応話速変換方法を用いて伸長したときの伸長率は, 単語発 話終了時の遅延時間が許容限以下になるように制御する必 要があり, 今後の検討課題である.

一方, 音声短縮 “0.6x-quick” の平均値-134 ms と “0.6x$\mathrm{nC}$ " の平均値- $107 \mathrm{~ms}$ を比較したときの時間差は- $27 \mathrm{~ms}$ で あり，これは音声が進んでいるときの映像と音声の相対時 間差の許容限 $78 \mathrm{~ms}^{13}$ 以下である. 時間短縮はレコーダに よる “早見早聞き”などで実用に供されており, 映像のス キップフレーム等で映像音声の同期合わせが実現できてい ることからも，了解度を損ねることなく視聴できるメリッ トにつながると考えられる.

なお，これらの考察は 2 モーラの単語のみの結果からの 類推であることも含め, 実用に供するためには, リアルタ イムの話速変換手段の導入やそのアルゴリズムの定義など の課題があると考える.

\section{8. むす び}

話速変換による日本語音声の了解度の変化を, 音声伸張 “1.6x-slow”，音声短縮 “0.6x-quick” および原音と等速の 加工音声 “1.0x-altered” の 3 種類の話速において, バブル ノイズを印加した状態における二者択一型の DRT 了解度 試験で検証した（単純伸長・短縮試験）。その結果, 音声伸 張では無声破裂音と母音/i/で了解度が向上し, 音声短縮で 
は殆どの子音と母音で劣化がみられたが, 鼻音, 無声破擦 音, 母音/o/では大きな劣化がなかった。 これらの結果は, 音韻に着目した話速変換が有効であることを示唆している.

さらに，音声伸長においては，伸長によって了解度が向 上した無声破裂音について，C1 のみ伸長する “1.6x-C”, C1 と V1 を伸長する “1.6x-CV” および V1 のみ伸長する “1.6x-V” の CV 伸長 3 パターンと単純伸長 “1.6x-slow” と $\mathrm{DRT}$ で比較した（CV 伸長試験）。同様に，音声短縮にお いては, 短縮して了解度の劣化があった有声破裂音, 半母 音・流音，無声破擦音，および母音 $(/ \mathrm{a} /, / \mathrm{u} /, / \mathrm{e} /)$ につ いて， C1 以外を短縮する “ $0.6 \mathrm{x}-\mathrm{nC} ", \mathrm{C} 1$ と $\mathrm{V} 1$ 以外を短 縮する “0.6x-nCV” および V1 以外を短縮する “0.6x-nV” の CV 短縮 3 パターンと単純短縮 “0.6x-quick”をDRT で 比較した（CV 短縮試験）.

その結果，子音の話速の影響が支配的であることが確認 できたが，一方では，母音/u/を含む音節では子音を伸長し たことによる劣化が顕著であることや, 音声短縮において, 母音/i/を含む音節は，子音と/i/の両方を短縮しないほう が了解度向上につながることが判った。これらの結果を踏 まえ, 効果のある音韻だけを伸長する, あるいは, 劣化す る子音は短縮しない, といった音韻の特徵を捉えた適応話 速変換方法の提案を行った．また，この適応話速変換にお いて子音のみの伸長を行った場合には, 単純伸長よりも再 生時間が短く, そのため先行研究文献 4), 13) で示された時 間遅延の許容範囲内に収まり, 映像音声の同期についての 問題も解決できる可能性があることが示唆された.このよ うに適応話速変換は, 音声伸張による了解度の改善のほか, 了解度の劣化が少ない “早聞き”が可能になると考える.

今回の評価結果は, 語頭子音のみ異なる 2 モーラの単語に 着目した結果である. 今後は, 母音にはさまれた子音 $(\mathrm{VCV}$ 連鎖における C）の影響の検討や，会話音声での有効性に ついての検討, あるいは，使用環境を想定したノイズ重畳 による解析などを行う一方, 放送のリアルタイム性を考慮 したときの映像音声の相対時間差との関連性の検討などを 計画している. また, 今回の評価試験では話速を 1.6 倍と 0.6 倍で実施したが，伸長時に効果のある話速の範囲や，子 音ごとにどの話速まで聞き取れるかといった許容值あるい は限界值を見出すことも検討課題である.

\section{[文献〕}

1）今井, “[招待論文］ゆっくり話せば話がはやい (話速変換技術)”, 信 学技報, CQ2007-29, pp.85-89 (Jul. 2007)

2）今井, 都木, 安藤, 宮坂, “映像との同期を考慮した話速変換方式の一 検討”，信学技報，SP96-128，pp.7-14 (Mar. 1997)

3）中村, 清山, 池沢, 都木, 宮坂, “リアルタイム話速変換型受聴システ ム”, 音響学誌, 50， 7, pp.509-520 (Apr. 1994)

4）今井, 池沢, 清山，中村，都木，宮坂，中林，“ニュース音声を対象に した時間遅孔を蓄積しない適応形話速変換方式”, 信学論, J83-A, 8, pp.935-945 (Aug. 2008)

5）祼寝, “[解説] 聴覚補助のたあめの話速変換装置”, 信学誌， 78, 5, pp.462-465 (May 1995)

6) 被寝，池田，今村，泉，伊福部，松島，“難聴者による話速変換方式の 評価”，信学技報，SP1992-150，pp.25-31 (Mar. 1993)

7）安達, 小寺, 寺島, 前川, 館野, “デジタル音声処理の子音明膫度への
影響”，Audiology Japan，47，3，pp.181-191 (Jun. 2004)

8）大島, 西本, 渡辺, “視覚障害者用早口合成音声による慣れの効果”, 信 学技報, SP2005-81, WIT2005-43, pp.19-24 (Oct. 2005)

9）近藤, 泉, 藤森, 加賀, 中川, “二者択一型日本語音声了解度試験方法 の検討”，音響誌，63，4，pp.196-205 (Apr. 2007)

10) P. Boersma, D. Weeninck, "Praat: doing phonetics by computer," http://www.praat.org/, (2011)

11) Rice University: Signal Processing Information Base (SPIB), http://spib.rice.edu/

12) T. Shibuya, Y. Kobayashi, H. Watanabe, K. Kondo, "Differences in the effect of time-expanded and time-contracted speech on intelligibility by phonetic feature," Proc. IEEE ICASSP 2012, SPP6, pp.4489-4492 (Mar. 2012)

13）黑住，赤井田，岡田，“テレビの映像と音声の相対時間差に関する検討”, テレビ学技報, HIR'96-93, pp.37-42 (Oct. 1996)

14）沼畑，坂本，田中，今井，都木，鈴木，“単語知覚における話者映像と時 間伸張音声のずれの検知限および許容限”，信学技報，HIP2007-139, pp.55-60 (Dec. 2007)

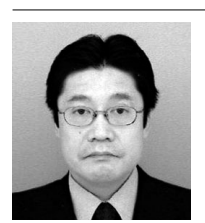

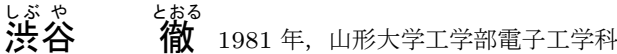
卒業. 1983 年, 同大大学院電子工学専攻修了. 同年, 宮城 日本電気 (株) 入社. 現在, 日本電気通信システム (株) 2009 年より，山形大学大学院理工学研究科博士後期課程 に在学. 話速変換に関する研究に従事. 学生会員.

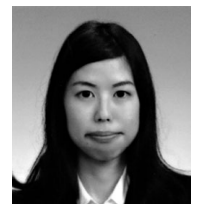

わたなべ渡辺 瞳 2012 年, 山形大学工学部電気電子工 学科卒業. 現在, 仙台高等専門学校勤務. 山形大学在学 中，音声システムの日本語了解度に関する研究に従事.

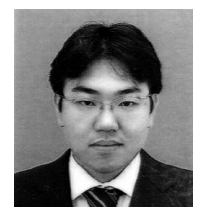

らばや林 洋介 2008 年, 山形大学工学部電気電子工 学科卒業. 2010 年, 同大大学院理工学研究科博士前期 課程修了. 現在, 同大大学院博士後期課程在学中. 主と して音声システムの日本語了解度の推定に関する研究に 従事.

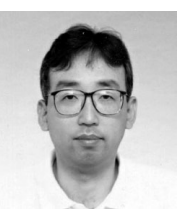

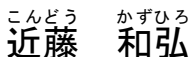

近藤 和弘 1982 年, 早稲田大学理工学部電子通 信卒業. 1984 年, 同大大学院理工学研究科修士課程修 了. 同年（株）日立製作所入社. 1992 年，(株）テキサ ス・インスツルメンツ入社. 1999 年, 山形大学工学部准 教授. 主として通信用音声・音響信号処理システムの研 究教育に従事. 工学博士. 